\title{
State Support of Russian Agro-industrial Complex at the Federal and Regional Levels on Entering the Global Market
}

\author{
Irina Y. Soldatova ${ }^{1}$, Victor N. Ovchinnikov ${ }^{1}$, Nikolai G. Kuznesov ${ }^{2}$ and Alla A. Lisochenko ${ }^{3}$ \\ 1. South Federal University, Rostov on Don 344022, Russia \\ 2. Rostov State University of Economics, Rostov on Don 344022, Russia \\ 3. The Ministry of Agriculture and the Foodstuffs of the Rostov Region, Rostov on Don 344022, Russia
}

Received: November 7, 2011 / Published: February 20, 2012.

\begin{abstract}
The main subject of the report consists in showing positive course of Russian agriculture over the last years-entering the global market. That's why it is essential to make following steps to support manufactures aiming them more actively at export: to develop export operations; to develop actively agro-industrial complex perspectives for entering the WTO; to ensure the food safety of agro-industrial complex while exporting the products; in the context of globalization Russian regions are entering more actively the global market as the relatively independent subjects of international economical relationships. The food safety of Russia-such condition of the state economy, when food independence of the country is provided, provision; physical and economic utility of food products is guaranteed by the state and corresponds to requirements of the legislation of the Russian Federation in safety and quality. Participation in the WTO gives to the country set of advantages in the decision food independence. In the world, the country and in region management of efficiency agriculture with a view of advancement to food safety, should be coordinated necessarily with food independence. State support of the Russian agro-industrial complex on the federal and regional levels when entering into the world market-is a factor of the formation of a new geopolitical status of Russia in the world arena, it is the new selection mechanism of the development of globalization processes in favor of the active participation of the agro-industrial complex of Russia in the world economy.
\end{abstract}

Key words: Export of agro-industrial complex, state support of agro-industrial complex, the introduction of agro-industrial complex of Russia into the WTO, food safety, regional agro-industrial complex.

\section{Introduction}

State support of the Russian agro-industrial complex on the federal and regional levels when entering into the world market-is a factor of the formation of a new geopolitical status of Russia in the world arena, it is the new selection mechanism of the development of globalization processes in favor of the active participation of the agro-industrial complex of Russia in the world economy [1-3].

Entering the world market of the Russian agro-industrial sector is important because of the

Correspondence author: Irina Y. Soldatova, Ph.D., professor, research field: agriculture.E-mail: sold@aaanet.ru. following factors:

(1) The state should develop a complex of measures for the protection of the agro-industrial complex of the national economy in the conditions of global competition;

(2) It will take a long time to make changes in the Russian legislative system, the system of quality control and tariff scale;

(3) Entry into the world market, in the WTO, is largely a political objective in the context of the world economy and the trend toward globalization;

(4) Russian companies will resist the expansion of foreign companies, from countries-members of the WTO; 
(5) It is necessary to activate the real fight against corruption in power structures, reduction of bureaucratic costs of the Russian business;

(6) Activation of explanatory work of the state in relation to the target audience on the issues of accession to the WTO is required.

Russian agro-industrial sector must necessarily enter into the world market, despite the ambiguity of the situation in this matter. Nevertheless, according to the authors there are much more positive trends, in the long-term perspective. AIC must be obligatory supported by the government on condition of food security provision. It is necessary to provide regional support for the agro-industrial complex at the entrance into the world market.

The entry of the agro-industrial complex of Russia into the world market, the WTO should move more actively and positively. The WTO is a necessary condition for entry into the Organization for economic cooperation and development, and in the future-for the formation of a common European economic space.

\section{Export Orientation of the Agro-industrial Complex in Russia}

Over the last years the growth of main agricultural products (corn, potatoes, vegetables and meat) is observed in the country's agriculture (Table 1).

The amount of grain production is sufficient to fulfill all domestic needs, including growth of Russian export potential. In 2011 the grain crop in net weight is expected to reach 90 million tons (Fig. 1). Taking into account the carryover production at the beginning of the season and the volume of domestic consumption-72 million tones, it means that the 2011-2012 export potential for agriculture is estimated at the level of 20 million tones.

Production of meat and poultry for slaughter at the year results is planned to reach 11 million tones, which is 450 thousand tones more than in 2010. In 2011, Russia started exporting sugar for the first time, this year a record crop of sugar beet has been harvested-40 million tones. Predicted export is 200 thousand tons. Sunflower oil export will increase by $25 \%$ and will be 500 thousand tones (Fig. 1).

Considering such a dynamic development, it becomes apparent that export will be the one of the main points of agricultural growth in the long term prospects.

To solve this problem the measures of the state support will be applied in following strategic directions of the industry: logistics and infrastructure; processing; small farms; melioration and insurance; sustainable rural development.

Implementation of the state support policy in the agricultural sector must be accompanied by the serious assessment of potential conflicts of the objectives and distortions that can inevitably arise in the regulatory process. In Table 2 the major possible consequences and distortions, arising from the application of the methods supporting agricultural producers are systematized [4].

Table 1 Agricultural production in the Russian Federation in all categories of farms, million t.

\begin{tabular}{|c|c|c|c|c|c|c|c|c|c|c|c|c|}
\hline & 2000 & 2001 & 2002 & 2003 & 2004 & 2005 & 2006 & 2007 & 2008 & 2009 & 2010 & $\begin{array}{l}2000-2010 \\
\text { (annual average) } \\
\text { per year }\end{array}$ \\
\hline $\begin{array}{l}\text { Grain (in weight after } \\
\text { processing) }\end{array}$ & 65.5 & 85.2 & 86.6 & 67.2 & 78.1 & 77.8 & 78.2 & 81.5 & 108.2 & 97.1 & 61.0 & 80.6 \\
\hline Sunflower & 3.9 & 2.7 & 3.7 & 4.9 & 4.8 & 6.5 & 6.7 & 5.7 & 7.4 & 6.5 & 5.3 & 5.3 \\
\hline Potatoes & 34.0 & 35.0 & 32.9 & 36.7 & 35.9 & 28.1 & 28.3 & 27.2 & 28.8 & 31.1 & 21.1 & 30.8 \\
\hline Vegetables & 12.5 & 13.3 & 13.0 & 14.8 & 14.6 & 11.3 & 11.4 & 11.5 & 13.0 & 13.4 & 12.1 & 12,8 \\
\hline $\begin{array}{l}\text { Cattle and poultry for } \\
\text { slaughter (net weight) }\end{array}$ & 7.0 & 7.0 & 7.3 & 7.7 & 7.8 & 7.7 & 8.1 & 8.7 & 9.3 & 10.0 & 10.5 & 8.3 \\
\hline Milk & 32.3 & 32.9 & 33.5 & 33.4 & 32.2 & 31.1 & 31.4 & 32.2 & 32.4 & 32.6 & 31.9 & 32.3 \\
\hline Eggs (billion) & 34.1 & 35.2 & 36.3 & 36.5 & 35.8 & 36.9 & 38.1 & 37.8 & 38.0 & 39.4 & 40.6 & 37.1 \\
\hline
\end{tabular}




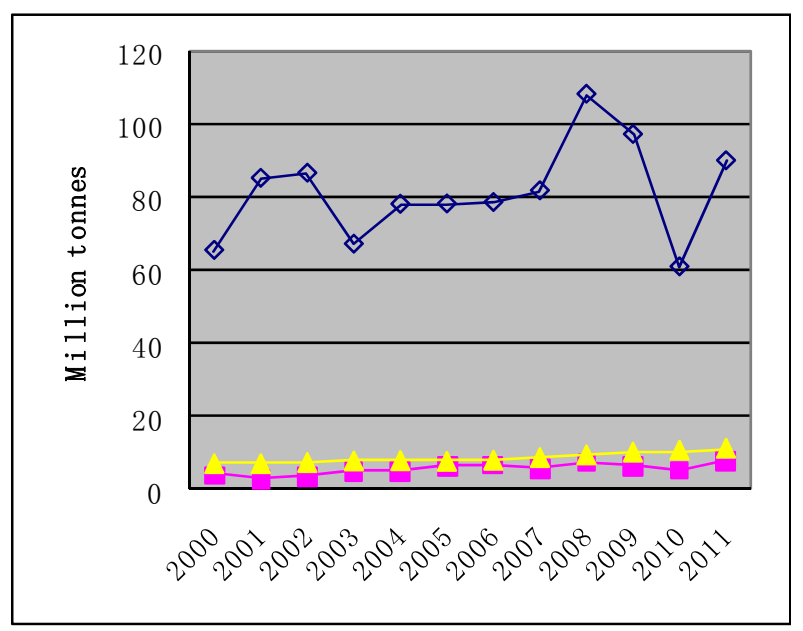

Fig. 1 The amount of grain, sunflower and meat production cutline in the Russia.

According to Managing Director of World Bank Ms. Okonžo-Iweala [5], announced at the international economic forum in Saint Petersburg in 2010, Russian
Agriculture has the potential not only to meet domestic demand for the main groups of food products, but also to make a significant contribution to food safety worldwide. There are $9 \%$ of the world's arable land and $25 \%$ of fresh water on the territory of Russia. However, it will be possible to take advantage of this economic potential only if this sphere is able to attract investments actively for the modernization of producing and processing facilities on the basis of modern technologies.

If we talk about the future and new export products, Russia can "close" their needs on poultry meat and some needs on pork in 2013 at the expense of its own production. New sites-cattle breeding complexes and processing productions are being developed according to export orientation to produce competitive quality products.

Table 2 Distorting effects of application of the methods supporting agricultural producers.

\begin{tabular}{|c|c|}
\hline \multicolumn{2}{|c|}{$\begin{array}{l}\text { Methods of } \text { Distorting consequences of state support } \\
\text { state support }\end{array}$} \\
\hline $\begin{array}{l}\text { Stimulation of } \\
\text { the national } \\
\text { output growth }\end{array}$ & $\begin{array}{l}\text { - the tendency of growth of the producers' total income will be weakened by the corresponding falling of the price; } \\
\text { - the national agricultural policy acquires international consequences according to the degree of influence on the } \\
\text { volume of supply of agricultural products; }\end{array}$ \\
\hline $\begin{array}{l}\text { The policy } \\
\text { price parity }\end{array}$ & $\begin{array}{l}\text { - formation of the agricultural products surplus; } \\
\text { - growth of the prices for agricultural products on the domestic market, the decline in consumption volume; } \\
\text { production; } \\
\text { - worsening of the social welfare due to inefficient funds' reallocation in the agrarian sphere; } \\
\text { - deformations of the world market of the agricultural production related to the breaking of market signals; }\end{array}$ \\
\hline Import quotas & $\begin{array}{l}\text { - moderating influence on the reduction of the production costs of domestic producers; } \\
\text { - high level of transactional costs related to the introduction of quotas and monitoring its compliance; }\end{array}$ \\
\hline $\begin{array}{l}\text { Taxes } \\
\text { imports }\end{array}$ & - growth of prices for agricultural products; \\
\hline $\begin{array}{l}\text { Structural } \\
\text { Policy }\end{array}$ & $\begin{array}{l}\text { - as migration from rural areas increases, the value of expenses providing public services per capita rises; } \\
\text { - "viability" of agricultural areas reduces in the long term prospects; }\end{array}$ \\
\hline $\begin{array}{l}\text { Direct income } \\
\text { support }\end{array}$ & $\begin{array}{l}\text { - } \text { considerable budget expenses; } \\
\text { - problem of administrative control and the high level of transaction costs; } \\
\text { slowdown of structural changes in agriculture formation of the non-rational expectations of agricultural producers; }\end{array}$ \\
\hline $\begin{array}{l}\text { Subsidizing } \\
\text { production } \\
\text { costs }\end{array}$ & $\begin{array}{l}\text { - increasing of budgetary expenditure; } \\
\text { - policy is successful, if it is not in conflict with the price policy of the resources' producers; }\end{array}$ \\
\hline Price support & $\begin{array}{l}\text { - reaction of producers is manifested in the long term prospect; } \\
\text { - it's difficult to forecast the price changes for the other products in the long term prospect; } \\
\text { - the more compensative payments lead to the world price falling, the greater subsidies are required ; } \\
\text { - import substitution and export promotion may have a depressive effect on world prices; }\end{array}$ \\
\hline $\begin{array}{l}\text { Limiting } \\
\text { volume } \\
\text { proposals }\end{array}$ & $\begin{array}{l}\text { - increasing of budgetary expenditure for compensative payments reduction in the total income of agricultural } \\
\text { producers; } \\
\text { - high level of transactional costs in the calculation and introduction production quotas for monitoring their } \\
\text { compliance; } \\
\text { - deterrent effect on reducing production costs by national manufacturers; } \\
\text { - rising costs of entry into the industry and expanding production. }\end{array}$ \\
\hline
\end{tabular}


The main task of the State support for the agro-industrial complex is to achieve targets established with the food safety Doctrine in order to consider $[6,7]$ the country to be independent from exports and imports. The share of it's own production should reach: grain-95\%, milk- $90 \%$, meat- $85 \%$, sugar- $80 \%$, plant oil- $80 \%$.

The Russian Ministry of agriculture and food provision is working at the second phase of the State development programme of the agricultural sector, for the period from 2013 to 2020 years. All support measures, which are currently in force, will be saved for farmers, in the new document. They are: subsidizing of the interest rate on loans, development of innovative component industry, regulation of agricultural products' markets, technical and technological upgrading, as well as a wide range of measures aimed at the sustainable development of rural territories [8].

\section{Problems of Russia's Entering the WTO}

While Russia's entering the World Trade Organization (WTO), principally new organizational and legal environment can be created for the agricultural business, it causes the mixed reaction in the country. There is a possibility of a number of positive and negative effects of Russia's entering the WTO.

The experience of recent years shows that the WTO countries with developed market economies foster entering their markets the goods from developing countries, introducing international standards in the field of labor legislation, health and the environment protection. Breaking these standards by developing countries because their poverty is considered as a fact of unfair competition by the developed countries. These countries impose trade sanctions, which make developing countries even more backward.

While Russia's entering the WTO there appears the necessity for transition of enterprises to international quality standards. To reduce competition from importers it is necessary to pay more attention to the technological processes of growing, processing and storing agricultural products. Quality and safety of food greatly depends on the technological level of industries, technologies, qualification of personnel. The significant depreciation of fixed assets, the lack of modern equipment does not allow many companies to process agricultural raw materials complexly and use modern waste processing technologies. Transition to the highest standards of quality must be due to the reconstruction and upgrading of food and processing industries.

In terms of macroeconomics, Russia's entering the WTO is logical and inevitable, as the country cannot develop in isolation from the civilized world, outside the world economic system and without integration into the global economy and trade.

Russia's joining the WTO is determined by the strategy of modern foreign policy of Russia, which aims to integrate effectively into the global economy and international trade.

Membership in this influential international organization will enable our country [9]:

- to provide supportive, stable and non-discriminatory conditions for Russian exporters of goods and services to foreign markets;

- to provide adequate protection of domestic producers in an open economy;

- to ensure predictability, transparency and uniformity of legislation for foreign economic activities;

- to influence on the creation of multilateral trade rules, taking into account Russian national interests.

Rules and regulations of the WTO will create for the agricultural business principally new organizational and legal environment. They are:

- improving the efficiency of agricultural production (access to cheaper components and raw materials, new technologies in agro-industrial complex);

- increasing the share of agricultural export for selected commodity items in total volume (production of organic food); 
- introducing commonly excepted world standards;

- adequate protection of domestic producers in a reasonably open economy;

- development of international cooperation in agricultural production, agricultural food trade.

The head of the Russian Government V. Putin says [10] that the representatives of various sectors have different attitudes towards Russia's joining the WTO. Putin has a great hope that negotiations on Russia's entering the WTO would be completed in 2011, the main obstacles being of a political nature.

"We want to join the World Trade Organization, we have set ourselves this task and purpose, we believe that this will have a positive impact on the Russian economy as a whole. WTO membership will increase the level of confidence in the Russian economy, its administrative and legal procedures ... My opinion is that in general it (Russia's joining the WTO) will be positive, but, I repeat, the country should join WTO under the standard conditions with binding agreements to protect certain sectors of the Russian economy for a certain period, till the moment when they become really competitive".

The President of Russia D. Medvedev said [11] that the additional measures on regulation of the Russian grain market are not currently required, the expected harvest in the amount of 90 million tons of grain, will not only provide the country with bread, but will also allow to return to the development of export potential.

"Today we have enough grain reserves, and the situation on the domestic grain market as a whole is quite stable," -said the head of the state. He noted that stocks of grain of the state intervention fund comprised 6.7 million tons. He noted that "the figures recorded at the level of 9 billion dollars till 2012 (state support) with a certain stage by stage decrease by 2017 ", that "the level of customs protection of basic agricultural goods stays sufficient, and for some of them, Russia has the right to increase the rates of import customs duties" [12].

Russian agro-industrial complex and machine-building are more likely to suffer from accession to WTO, and the greatest benefit will bring to the mining sector of the economy and construction, according to Russian Business Consulting studies (Fig. 2).

In the short term, problems may arise in individual enterprises, non-competitive now. Other factors, such as changes in foreign currency exchange rates, state of the world economic situation, investment activity will affect the Russian economy to a much greater extent. In the long-term, factor of Russia's participation in the WTO will provide absolute positive impact on economic growth in Russia, contributing to the development of trade and investment, stimulating competition in the domestic market, creating clear international legal framework for conducting domestic policy in the sphere of foreign trade regulation.

Possible losses of Russia from membership in the WTO, in the case of negative scenarios of the development of the situation, are as follows:

(1) Weakening of national sovereignty because of the increase of competitiveness;

(2) Many enterprises will not be able to withstand competition with the flow of foreign goods and services which are often cheaper and of high quality, working places will reduce;

(3) The cost of Russian competitive products will increase;

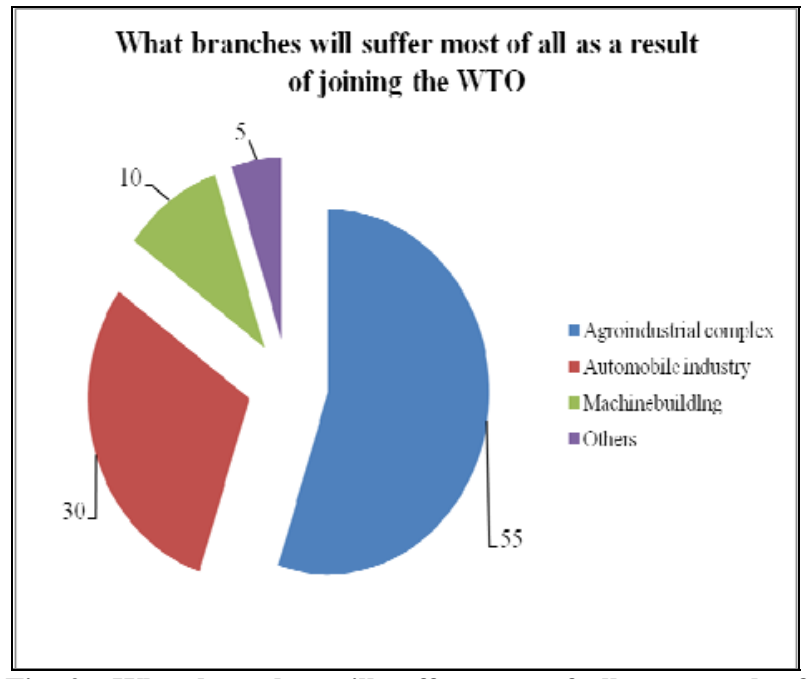

Fig. 2 What branches will suffer most of all as a result of joining the WTO. 
(4) More inflation and loss of competitiveness in the world market of production of energy-intensive industries (and the manufacturing industry);

(5) The WTO agreements prohibit the countries-participants in the provision of government subsidies, prohibitions relate primarily to the export subsidies in industry, which are not practically used in Russia, or subsidies for import substitution.

\section{Regional Agrarian and Industrial Complex of Rostov Region is Entering the World Market}

The agro-industrial complex of Rostov region is one of the leading in Russia. The area of farmland of the region takes the third place, and on the area of crops-the second place in the Russian Federation. The share of the Rostov region accounts for more than $4 \%$ of gross output of agriculture in Russia, more than $20 \%$ of sunflower production, more than $10 \%$ of grain production [13].

The Rostov region is the center of the grain-oil cluster of the South of Russia. Competitive advantages of the formed cluster are:

- Mainly export orientation and the favorable situation on the world market;

- the development of the infrastructure of grain export (14 modern terminals, located along the coast of the Azov sea and delta of the Don);

- favorable natural climatic conditions, geographical position; the establishment of agricultural holdings, which allow to form and strengthen the "value added chain";

- the development of production capacities. The main directions of the functioning of the agro-industrial complex are the production of grain, sunflower seeds, vegetables, livestock and their products, their processing with a subsequent delivery to the consumer (Table 3 ).

The Rostov region is the largest exporter in the South of Russia. According to the data for the year 2010 the share of the Rostov region in the total exports of the southern federal district was $25.7 \%$, which is the second largest result among subjects of the district after the Krasnodar region. Don ports annually handle up to $40 \%$ of Russian total agricultural exports. Rostov region provides $60 \%$ of Russian exports of vegetable oils and is capable to provide up to $30 \%$ of grain export annually. Export shipments are held in the 14 port terminals with the total capacity up to 10 million tons of grain a year [13].

Export of food products and raw materials is about $43 \%$ in the total export volume. Authors have in mind also the traditional export a significant part of the products in other regions of the country. The area supplies grain, fruits and vegetables, sunflower oil.

The culinary traditions of the Don cossacks are widely known outside of the Don krai, the dishes of the Don region cuisine and such brands as "Tsimlyanskoe champagne", vegetable oil "Golden seed", "Donskoye solnechnoye", meat products "Taurus", "Vepoz", "Indolina, "beer", "Baltika-Don”, canned vegetables "Khozjain (Master)", combine harvesters of "Rostselmash".

Table 3 The production of agricultural products in the Rostov region (thousand tons).

\begin{tabular}{|c|c|c|c|c|c|c|c|c|c|c|c|c|}
\hline & 2000 & 2001 & 2002 & 2003 & 2004 & 2005 & 2006 & 2007 & 2008 & 2009 & 2010 & $\begin{array}{l}2000-2010 \\
\text { (average for } \\
\text { the year) }\end{array}$ \\
\hline $\begin{array}{l}\text { Grain (weight after } \\
\text { processing) }\end{array}$ & $3,768.1$ & $6,122.8$ & $6,550.8$ & $3,711.4$ & $7,356.9$ & $6,467.7$ & $6,517.7$ & $4,228.2$ & $9,124.1$ & $6,780.6$ & $6,842.0$ & $6,133.7$ \\
\hline Sunflower & 888.0 & 579.1 & 882.1 & $1,192.9$ & $1,187.3$ & $1,584.5$ & $1,637.6$ & $1,199.9$ & $1,529.8$ & 966.3 & 901.1 & $1,140.8$ \\
\hline Potato & 395.5 & 591.0 & 450.3 & 492.1 & 560.3 & 639.3 & 610.7 & 500.4 & 380.2 & 305.4 & 284.5 & 473.6 \\
\hline Vegetables & 342.5 & 450.7 & 531.2 & 668.1 & 543.5 & 522.6 & 545.2 & 477.5 & 548.2 & 472.3 & 483.8 & 507.8 \\
\hline $\begin{array}{l}\text { Livestock and poultry } \\
\text { (weight alive) }\end{array}$ & 217.5 & 212.8 & 227.8 & 251.0 & 247.6 & 269.9 & 285.8 & 323.6 & 342.7 & 378.4 & 378.6 & 285.1 \\
\hline Milk & 835.9 & 871.7 & 921.9 & 932.8 & 904.5 & 872.8 & 884.0 & 952.8 & 995.5 & $1,035.3$ & $1,002.2$ & 928.1 \\
\hline Eggs, billion pieces & 992.6 & $1,061.9$ & $1,117.4$ & $1,186.5$ & $1,205.5$ & $1,392.7$ & $1,436.8$ & $1,474.2$ & $1,397.5$ & $1,484.7$ & $1,578.7$ & $1,302.6$ \\
\hline
\end{tabular}


State support of the agro-industrial complex of Rostov region is carried out in the framework of the Regional long-term target programs of development of agriculture and regulation of markets of agricultural products, raw materials and food in the Rostov region in 2010-2014, which includes 12 sub programmes. Five of them are directed on development of cattle breeding and dairy and beef cattle breeding, sheep-breeding, poultry farming and pig breeding. Three programs aimed at the development of plant growing: the preservation and restoration of fertility of soils of agricultural lands; development of viticulture; the development of fruit growing. Sub-program "Social development of rural areas" provides for subsidizing the costs of rural residents for the purchase of housing, school construction, financing of construction of gasification objects and water supply in rural areas.

In addition, the program includes a subprogram: development of small and medium agricultural enterprises and private farms, the development of food and processing industry and competition in the food market and subprogram improvement of cattle from leukemia.

In 2011 more than 6 billion roubles from the funds of the regional and federal budgets were sent to the agricultural producers of the Don area and agro-industrial companies. The volume of the budgetary funds in comparison with 2009 has increased twice.

State support of the agro-industrial complex aimed at:

(1) The creation of a new technological base, the use of modern equipment for the modernization of livestock farms, as well as enhancing the genetic potential of domestic cattle-breeding and the development of adequate fodder base;

(2) Accelerated transition to the use of new efficient and resource-saving technologies of delivery on the terms of leasing of high-tech facilities of agricultural machinery and equipment for the introduction of intensive agricultural technology. The agrarian industrial park will be created by including trade-exhibition complex, training center, experimental fields, agrarian technological laboratories and facilities for the training of machine operators;

(3) Creation of conditions for agricultural and other producers of agro-industrial complex for investment in modernization and technical re-equipment of production.

Investment policy in agriculture of the region is aimed at creation of conditions for attraction of investments on the basis of: improvement of normative legal base; the development of public-private partnership; state support of the implemented investment projects. In the region there was adopted "long-term Regional target program of support of export for 2011-2013", aimed at support of the enterprises-exporters of the region.

\section{Conclusion and Discussion}

The complex system support of the state sector, investments, new technologies, effective managers have been involved in this agriculture industry. The five key areas of the state's support for agriculture have been identified:

(1) Social development of the countryside-improvement of living conditions of citizens in rural areas, development of gasification and water supply in rural areas, development of a network of primary health care, physical culture and sports establishments in rural areas.

(2) Creation of the general conditions for agricultural performance-maintenance of soil fertility, development of the information management system, provision consultancy, participation of the agricultural producers' unions in formulating of the state agricultural policy.

(3) Development of the priority sub-sectors of agriculture, cattle breeding support, the development of reindeer and horse herding, sheep and goat breeding, carrying out the anti-epizootic measures, granting subsidies for the production of 1 liter of the 
merchantable milk, a partial reimbursement of the expenses for cattle and dairy-cattle in the agricultural organizations and farms. Planting is focused on the support of elite seeding, development of flax and canola production, planning the perennials.

(4) Achieving financial stability of the farms-agricultural producers receive subsidies from the federal and regional budgets for the partial reimbursement of the expenses at repaying interests on the investment and short-term loans.

(5) The regulation of markets for agricultural products, raw materials and food.

New directions for support of agricultural producers under the State programme up to 2020 will include: development of processing industries agro-industrial complex; development of land melioration; promotion of investment activity and innovative branch development, technical and technological modernization; development of the agricultural food market infrastructure; support for small businesses in rural areas; promotion of the efficient usage of agricultural land.

It will not only strengthen the position of Russia in the world agricultural market, but also improve greatly the quality of Russian products, the efficiency of agricultural business, incomes of agricultural producers. It is essential to enhance the competitiveness of agricultural products and to develop sustainable, responsible modern standards of quality, food production to improve the agricultural food export potential of Russia.

State support of the Russian agro-industrial complex on the federal and regional levels when entering into the world market-is a factor of the formation of a new geopolitical status of Russia in the world arena, it is the new selection mechanism of the development of globalization processes in favor of the active participation of the agro-industrial complex of Russia in the world economy.

Specific positive goal of joining the WTO for Russia are identified:
(1) Better as compared with the existing, non-discriminatory conditions of access of Russian goods to foreign markets;

(2) The international mechanism for settling trade disputes;

(3) The creation of a more favorable climate for foreign investment as a result of bringing the legislation in line according to the WTO standards;

(4) Expanding the opportunities for Russian investors in the WTO member countries;

(5) Creation of conditions for raising the quality and competitiveness of domestic products as a result of increase of flow of foreign goods, services and investments to the Russian market;

(6) Participation in the formulation of international trade rules in accordance with their national interests;

(7) Improving the image of Russia in the world as a full and equal participant of the international trade;

(8) The expansion of world trade zone, enhance the competitiveness of Russian companies;

(9) Increase of investment attractiveness of the Russian economy;

(10) Russia on the rights of the membership will receive the opportunity to participate in the formulation of the rules regulating international trade and investment, as well as an opportunity to defend its trade interests, through the WTO system of dispute settlement;

(11) Increased attention and responsibility in respect of intellectual property rights of Russian producers, consumers' rights;

(12) Simplification and rationalization of procedures for the confirmation of compliance of products with international standards;

(13) Cost reduction and elimination of duplication in the field of supervision and control over compliance with the requirements;

(14) In the long term, the system of management of external economic ties will become more stable. Businessmen for many years ahead will know what duty is set, at which point it will be applied; 


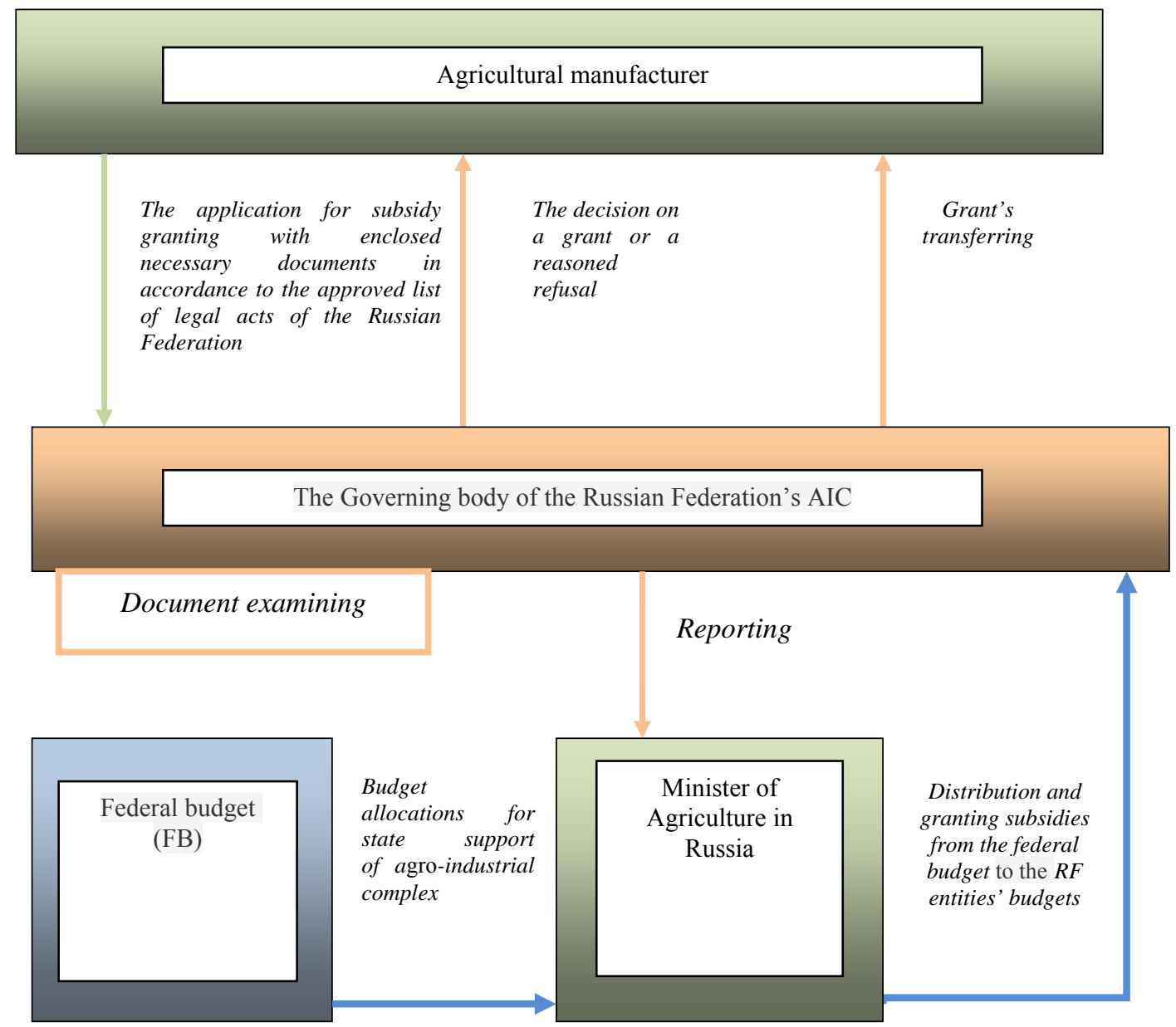

(15) Strengthening the power of law and reducing the number of permitting documents and increase in the degree of transparency of the system of regulation.

The top priority task for Russia is not so much the integration into the world market, as integration into the modern institutions of international regulation. Membership in the WTO will create favorable conditions for the formation and expansion of new sectors of the economy. It is on a post-industrial breakthrough, and not on a primitive protection of "domestic producers" that foreign economic doctrine of Russia should be aimed at.

The food safety of Russia-such condition of the state economy, when food independence of the country is provided, provision; physical and economic utility of food products is guaranteed by the state and corresponds to requirements of the legislation of the Russian Federation in safety and quality. Participation in the WTO gives to the country set of advantages in the decision food independence. In the world, the country and in region management of efficiency agriculture with a view of advancement to food safety, should be coordinated necessarily with food independence.

The development of the export potential of the region and raising the effectiveness of the functioning of the agro-industrial sector should be further the course of the regional state policy aimed at:

- supporting the production of plant growing, animal breeding;

- the implementation of economically significant regional programs;

- increasing the availability of short-term and long-term loans to agricultural and processing;

- organizations;

- assistance to improve the financial sustainability 
of small forms of farming in the village;

- providing advisory assistance to the agricultural producers;

- regulation of the markets of agricultural products, raw materials and food;

- support in the sphere of ensuring the quality and safety of food products.

In the world, the country and region management of agriculture with a view of advancement to food safety, should be coordinated necessarily with food independence [14].

\section{References}

[1] International congress "Open Russia: Partnership for modernization" [Online], Moscow on March 24-25, 2011, http://www.mcx.ru.

[2] Implementing Agriculture For Development. World Bank Group Agriculture Action Plan: By 2010-2012 July [Online], 2009, http://www.worldbank.org/ard.

[3] The Report on the Economy of Russia 2010-2011, http://www.worldbank.org/eca/rer (access June 25 2011).

[4] I. Soldatova, N. Kuznesov, K. Churikova, Management of the governmental support of Russian agro-industrial complex on entering the world market, in: The $5^{\text {th }}$ International Strategic Management Conference, Striking the Right Balance Between Existing Strategy and new Opportunities with Special Emphasis on Turbulent Markets, Stellenbosch-South Africa, July, 2009, p. 503.
[5] Okonzho-Invela, Managing director of the World bank Russian agriculture post crisis, in: St. Petersburg International Economic Forum, June 18, 2010.

[6] The Order of the Government of the Russian Federation, The Plan of Measures on Realization of Positions of the Doctrine of Food Safety of the Russian Federation, Moscow, March 17, 2010.

[7] The Decree of the President of the Russian Federation, About the Statement of the Doctrine of Food Safety of the Russian Federation, Moscow, 2010.

[8] E. Skrynnik, The National report on a course and results of realization in 2008 of a government program of development of agriculture and regulation of the markets of agricultural production, Raw Materials and the Foodstuffs on 2008-2012, Moscow, 2010.

[9] V. Mau, The Presidents of Russia and the United States once again decided to accelerate the entry of Russia into the WTO, Why s our country eager to do it?, June 30, 2010.

[10] V. Putin, Conference on the Financial Support for The Agricultural Sector, November 29, 2010.

[11] D. Medvedev, Meeting about Prospects of a Crop and a Situation in the Grain Market, Michurinsk, July 25, 2011, http://www.medvedev.kremlin.ru.

[12] V. Putin, Russia's Accession to the WTO is a Question of a Political Nature, Moscow, 2010.

[13] Ministry of Agriculture and the Foodstuffs of the Rostov region [Online], 2010, http://www.don-agro.ru.

[14] I. Soldatova, V. Ovchinnikov, M. Chernishev, N. Kuznesov, The Management of the Agriculture of Russia While Maintaining Food Security in the Globalization, China-USA Business Review 10 (9) (2011) 785-792. 